PROBLEMS

OF MANAGEMENT IN THE $21^{\text {st }}$ CENTURY Vol. 16, No. 2, 2021

\title{
AN OVERVIEW OF BIG DATA IN COVID-19 AS A CONTRIBUTION TO THE MANAGEMENT OF SCIENTIFIC AND TECHNOLOGICAL KNOWLEDGE
}

\author{
Jorge Magalhães \\ Ministry of Health of Brazil, Brazil \\ University NOVA of Lisbon, Portugal \\ E-mail: jorge.magalhaes@fiocruz.br \\ Henrique Koch Chaves \\ Ministry of Health of Brazil, Brazil \\ E-mail: henrique.chaves@far.fiocruz.br \\ Viviane Theodora Muniz \\ Merck S.A., Brazil \\ E-mail: vivianetmuniz@gmail.com
}

\begin{abstract}
In times of pandemic, rapid sharing of research data is urgently needed, as is the intensification of networking. The COVID-19 pandemic brought a new perspective in relation to knowledge management in various organizational means, whether through the search for innovation or the improvement of its processes. Thus, to calculate the state of the art and track scientific and technological knowledge in the COVID-19 spectrum, the keyword "Coronavir*" was used in the PubMed and Espacenet databases.

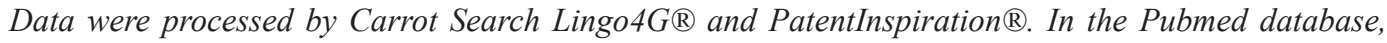
1,000 documents were retrieved, which were organized into 81 groups of sub-themes, with emphasis on the sub-theme "treatment during coronavirus disease", with 188 articles (18.8\% of the total). Regarding technological innovation, China and the United States were the countries that filed the most patent applications, especially in 2020 and 2021, corresponding to 68.5\% of the total. The first 4 (four) applicants with the highest number of patents were Pfizer, Gilead Sciences Inc., Center Nat Rech, Crucell Holland. The results obtained over a period of time demonstrate a partnership between universities and companies towards the fight against the pandemic. The tools for identifying, extracting and processing data (or free), are needed efficiently in the management of scientific and technological knowledge in COVID -19, thus being able to contribute to more assertive decision-making at various organizational levels.
\end{abstract}

Keywords: Big Data, COVID-19, Knowledge Management, coronavirus patents

\section{Introduction}

The 21 st century is known as the information age and has $40 \%$ of the population connected to the Internet (Magalhães et al., 2017; McKinsey Global Institute, 2011). In this sense, O'Reilly (2007) suggested the term Big Data as a gigantic database updated in real time. Big data easily reaches thousands of terabytes of storage in different formats (O'Reilly, 2007a). Traditional relational database management systems cannot handle these large masses of data (Magalhães \& Quoniam, 2013; Quoniam, \& Lucien, 2010). Big Data drives a new generation of methodologies developed to extract economic and strategic value from a large and varied 
Jorge MAGALHÃES, Henrique KOCH CHAVES, Viviane Theodora MUNIZ. An overview of big data in Covid-19 as a contribution to the management of scientific and technological knowledge

volume of data (structured and unstructured), enabling high-speed capture and analysis (Gray

et al., 2012; InfoVis: Wiki, n.d.; O’Reilly, 2007b).

Initially, this exponential data volume met the criteria of 3Vs: Volume, Variety and Velocity (Laney, 2001); later, 2 Vs were added: the Veracity and Value attributes. Some authors even attribute the last $3 \mathrm{Vs}$, such as Veracity, Versatility and Feasibility, where the combination of all "Vs" generates the "V" for Value (Aleixo \& Duarte, 2015). According to Minelli et al (2013), Big Data is divided into perfect data storm, perfect convergence storm and perfect computing storm, and the latter is the result of 4 phenomena: Moore's law, mobile computing, social networks, and computing in cloud (cloud computing). This collection of data must be treated to present information researched in a selective and objective way to increase business intelligence, in addition to allowing for an improvement in the decision-making process (Minelli et al., 2013).

Regarding Health, it is considered a global public good (Buse \& Waxman, 2001; Haines et al., 2009; Vance et al., 2009). Reflecting on Health brings with it challenges and opportunities in the globalization process. This process is the catalyst for the evolution of the term "Global Health". Global health can be understood at the same time as a condition, an activity, a profession, a philosophy, a discipline, or a movement. However, it must be considered that there is no consensus on what Global Health is, nor a single definition, and its field of action has imprecise limits (Fortes \& Ribeiro, 2014), however, it is indisputable that health is lived in times of globalization (Koplan et al., 2009). Therefore, it is essential to seek to identify, extract and treat the Big Data of Health in this globalized world, to focus on essential information for decision makers in the present century.

Nevertheless, the management of this knowledge is not considered trivial since the Open Science approach is imminent. Open science is a model of scientific practice that, in line with the development of digital culture, aims to make information available in a network, as opposed to closed research in laboratories. The term also refers to the generation of openly shared research materials without the need for patents. In this context, the European Community has shown maturity in this area with the promotion of Open Science (Resolução Do Conselho de Ministros n. ${ }^{\circ}$ 20/2016 - Diário Da República n. ${ }^{\circ}$ 70/2016, Série I de 2016-04-11, 2016). Thus, organizations that deal with health research must seek a better management of knowledge management of Big Data in Health, increasingly in an open science, portraying a collaborative and constructive intelligence for society.

The Covid-19 pandemic was first reported in December 2019 in Wuhan, China's Hubei province, and isolated for the first time on January 7, 2020 (Agbehadji et al., 2020; Esakandari et al., 2020). The outbreak of the new coronavirus 2019 disease (COVID-19) has been declared by the World Health Organization as a global public health emergency of international concern (Strabelli \& Uip, 2020). The new virus was initially referred to as "new coronavirus 2019" (2019-nCoV) and later as "Severe Acute Respiratory Syndrome Coronavirus type 2" (SARSCoV-2), resulting in a global human tragedy like never before in other pandemics (Zhou et al., 2020). In just a few weeks, the COVID-19 pandemic caused a deep crisis that changed political, economic and social dynamics.

Due to advances in the fields of computing and communication technologies, Big Data can help to process the large amount of data from public health surveillance and thus corroborate for the monitoring of epidemic outbreaks in real time (Wong et al., 2019). Therefore, this work aims to contribute to knowledge management in times of Big Data in COVID-19 through an overview of scientific and technological information. 
Jorge MAGALHÃES, Henrique KOCH CHAVES, Viviane Theodora MUNIZ. An overview of big data in Covid-19 as a contribution to the management of scientific and technological knowledge

PROBLEMS

OF MANAGEMENT IN THE $21^{\text {st }}$ CENTURY Vol. 16, No. 2, 2021

\section{Research Methodology}

The methodology used was to identify the state of the art in indexed databases such as PubMed and Web of Science. Likewise official websites like the World Health Organization (WHO). The keyword used to track scientific and technological knowledge in the COVID-19 spectrum was "Coronavir*". The basis for exemplifying scientific knowledge was PubMed: abstracts of medical papers from the PubMed database provided by NCBI. As for technological knowledge, it was Espacenet (a free online service for searching patents and patent applications developed by the European Patent Office - EPO).

With regard to the extraction and processing of scientific and technological Big Data, the Carrot $^{2}$ search engine was used (https://search.carrot2.org/\#/search/web) e o patentinspiration (https://www.patentinspiration.com/), respectively.

\section{Research Results}

A worldwide overview of COVID-19 cases is provided by Johns Hopkins University. The data are already processed and Big Data information available in COVID-19 regarding the world epidemiological scenario (figure 1). As of December 13, 2021, there are 270,650,863 confirmed cases, 8,475,424,722 total vaccine doses administered and 5,310,785 deaths by Covid-19.

\section{Figure 1}

Global Cases of COVID-19

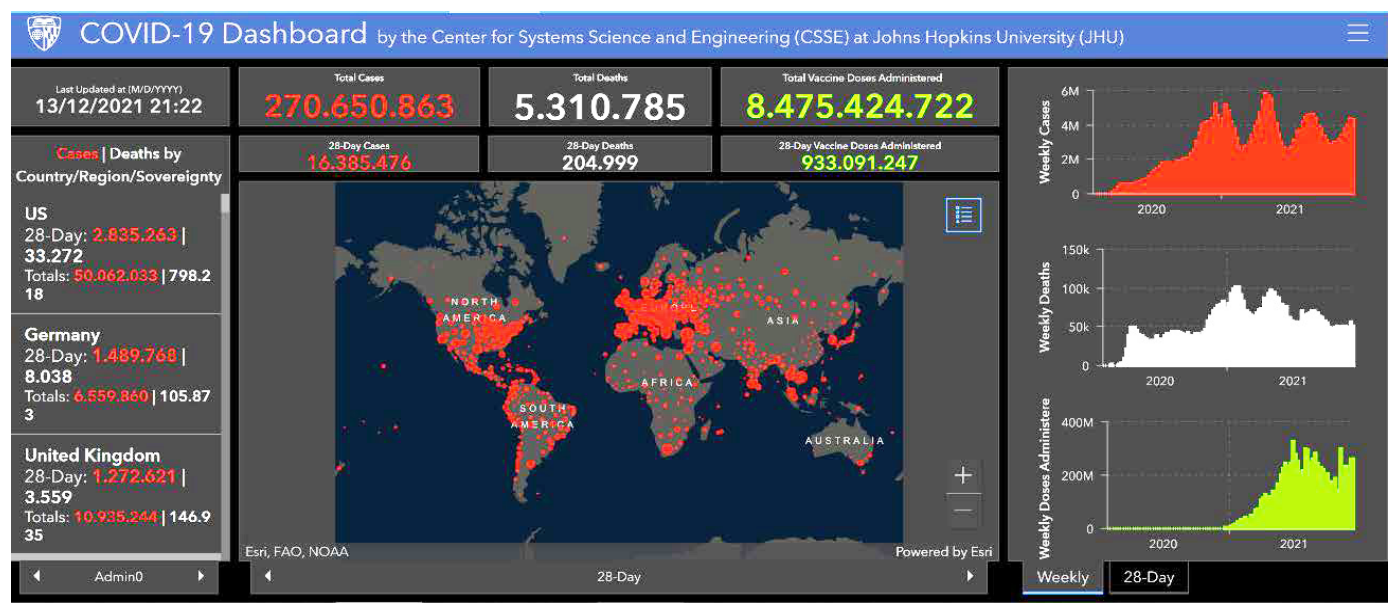

Source: COVID-19 Dashboard by the Center for Systems Science and Engineering (CSSE) at Johns Hopkins University, 2021 (https://coronavirus.jhu.edu/map.html ).

As described in the methodology, the scientific knowledge in covid-19 was identified, exemplified in the Medline biomedical literature base - base with more than 33 million citations in PubMed, has 233,262 scientific productions for the search term "Coronavir* or MERS$\mathrm{CoV}^{*}$ or SARS-CoV* or COVID* or HCoV or SARS or MERS". However, aiming to focus on a single term for scientific and technological productions, as well as to identify clusters and knowledge networks, the term "coronavir*" was used for both, where 1,000 most relevant documents were retrieved. These results and their correlations are visualized in Figure 2. These documents were aggregated into sub-themes that correlate with new keywords that were most characterized (appeared) within each scientific production analyzed by the algorithm. 
Jorge MAGALHÃES, Henrique KOCH CHAVES, Viviane Theodora MUNIZ. An overview of big data in Covid-19 as a contribution to the management of scientific and technological knowledge

Based on the central theme (coronavir*), subthemes were organized according to the

\begin{tabular}{|l} 
PROBLEMS \\
OF MANAGEMENT \\
IN THE 21 $1^{\text {st }}$ CENTURY \\
Vol. 16, No. 2, 2021 \\
\hline 105
\end{tabular}
new keywords identified by the algorithm as 'most relevant'. Thus, after "mining" the data, the most "evident" terms (the most repeated), generated 81 clusters within 06 major themes (see figure 2).

\section{Figure 2}

\section{Covid-19 Scientific Knowledge Cluster in the PubMed Database}

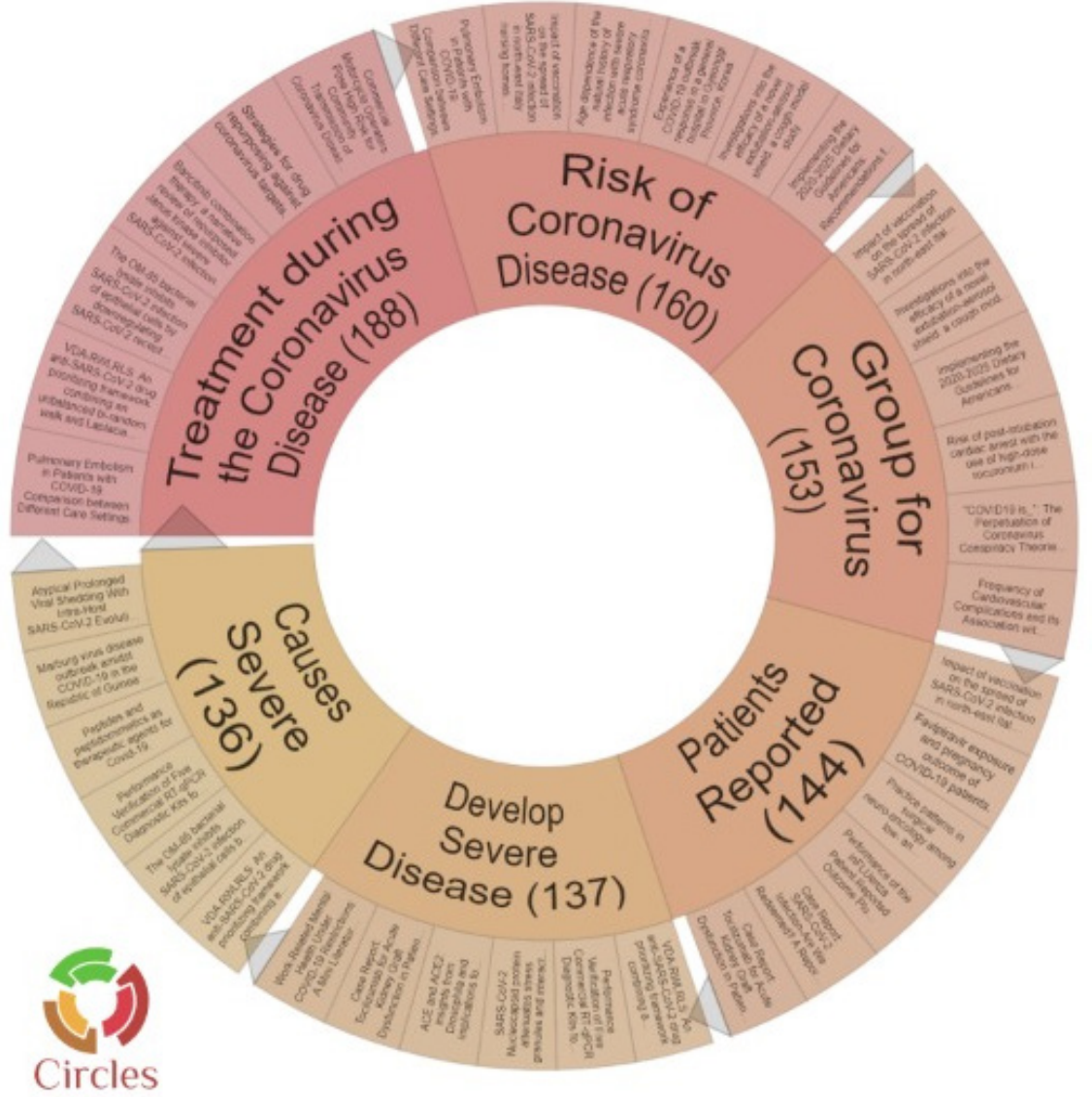

Source: created by the author using Carrot $^{2}$.

Regarding the technological knowledge expressed by patents, 6,036 documents were identified (Figure 3). 
Jorge MAGALHÃES, Henrique KOCH CHAVES, Viviane Theodora MUNIZ. An overview of big data in Covid-19 as a contribution to the management of scientific and technological knowledge

OF MANAGEMENT IN THE $21^{\text {st }}$ CENTURY Vol. 16, No. 2, 2021

106

Figure 3

Countries of Patent Family Applicants for Coronavirus

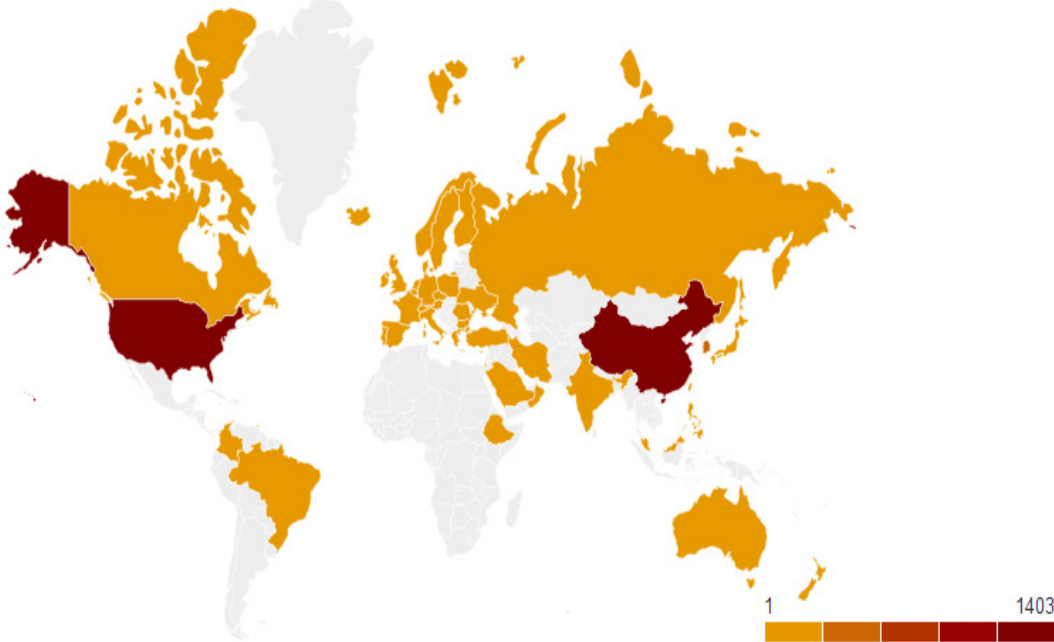

Source: created by the authors using European Patent office by Patent Inspiration ${ }^{\circledR}$. December, 2021.

It is noteworthy that the darker the color displayed in the country, it represents the country with the greatest number of technological knowledges expressed in patent filing. Note that the most accentuated color for red (China and USA) is where most are patents registered.

Figure 4 shows the evolution of patents over the last 20 years. Highlight for an abrupt growth in the years 2020 and 2021.

\section{Figure 4}

Evolution of Patents from 2002 to 2021

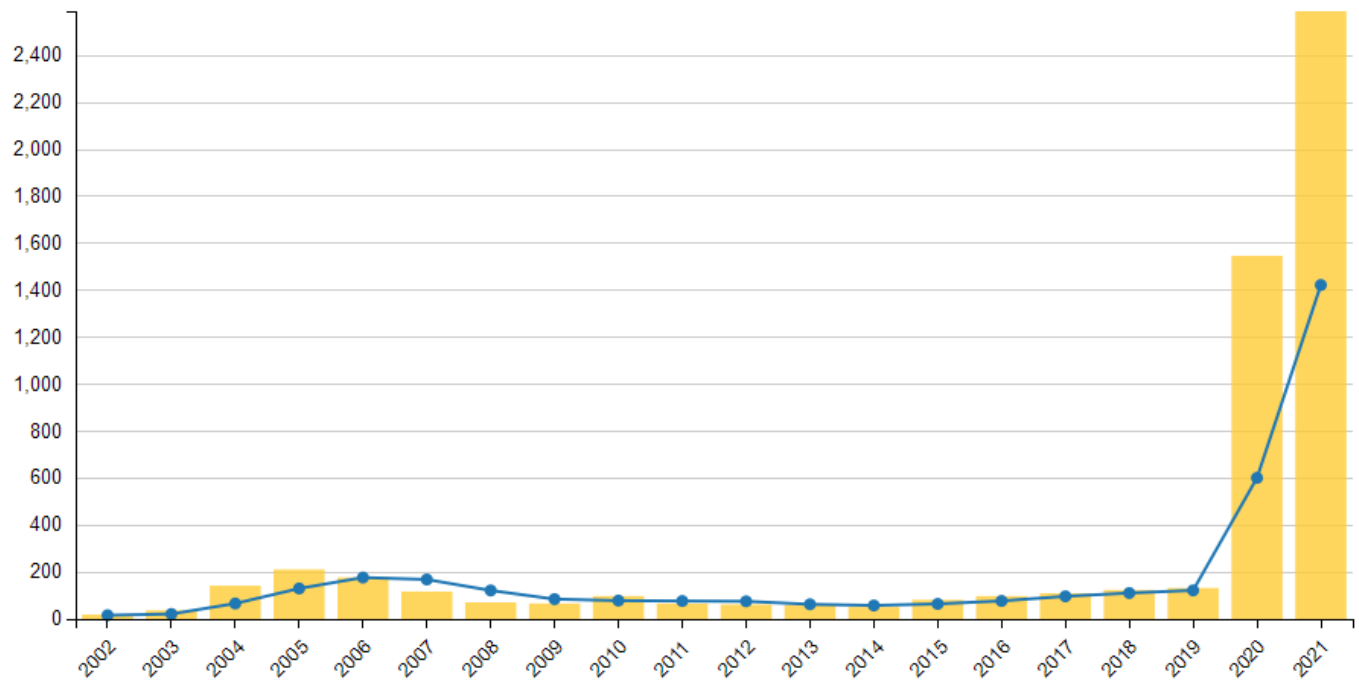

Source: created by the authors using European Patent office by Patent Inspiration ${ }^{\circledR}$. December, 2021. 
Jorge MAGALHÃES, Henrique KOCH CHAVES, Viviane Theodora MUNIZ. An overview of big data in Covid-19 as a contribution to the management of scientific and technological knowledge

\section{Discussion}

As the world lives the exponential era of data in all areas of science and, in Health it is no different, the development of scientific investigation is no longer linear. The speed of this evolution is accelerating. There is a new research paradigm, with new ideas and a very accelerated change in this new era of knowledge. As an example, one can mention the sequencing of HIV (human immunodeficiency virus) taking 15 years. The sequencing of SARS (Severe acute respiratory syndrome) was obtained in just 21 days (Projeto Genoma Humano: Um Retrato Da Construção Do Conhecimento Científico Sob a Ótica Da Revista Ciência Hoje, n.d.; The Digital Universe in 2020: Big Data, Bigger Digital Shadows, and Biggest Growth in the Far East by John Gantz and David Reinsel Sponsored by EMC, 2012).

For technological advances in all areas of science to continue rapidly, it is necessary to treat large volumes of data in an innovative way. Quoniam et al (2015) highlights that $43 \%$ of all daily bytes on the Web are related to Health and $47 \%$ of these are public health (Magalhaes \& Quoniam, 2015). Thus, the exhaustive volume of data requires organization and structuring for the possible subsidy of the decision maker, which has led organizations to create search tools on specific websites in order to extract and process the data to obtain essential information (Kira TARAPANOFF (org.), 2015).

Open or paid search tools are increasingly common and present a plethora of competitive and/or collaborative intelligence, such as text mining, datamining, etc. The practical result of the extracted and processed data, generate essential information and are configured as useful, reasonable and strategic to streamline the decision process (Magalhães et al., 2020).

Coronaviruses are a group of large, enveloped, positive-sense, single-stranded RNA viruses belonging to the order Nidovirales, family Coronaviridae, subfamily Coronavirinae (Bastos, 2020). In late 2019, a new type of coronavirus was discovered, provisionally called 2019-nCoV and later called SARS-CoV-2, due to its similarity to SARS-CoV. The disease caused by the virus was officially named Coronavirus Disease 2019 (COVID-19) by the WHO (Coronavirus Disease, 2019.).

Saxena et al (2020) and Bonilla-Aldana et al (2020) describe that until 2019, only six coronaviruses caused disease in humans: HCoV-229E, HCoV-OC43, HCoVNL63, HCoVHKU1, coronavirus with severe acute respiratory syndrome (SARS -CoV) and coronavirus with respiratory virus in the Middle East (MERS-CoV) (Bonilla-Aldana et al., 2020; Saxena, 2020). The first four are endemic locally and have been mainly associated with mild and limiting diseases, while the last two can cause serious illness. SARS-CoV and MERS-CoV are beta-coronaviruses and are among the pathogens included in the World Health Organization's Model List of Priority Diseases (Coronavirus Disease, 2019).

To identify, extract and process all scientific knowledge on coronavirus in a trivial way would be extremely tiresome and flawed by human limitation; since extracting all documents from the base and studying them punctually would take a long time of individual analysis. However, using search engineering algorithms and subsequent processing of this volume, it was possible to obtain, preliminarily, essential information to help in knowledge management. For example, the free platform Carrot Search Lingo4G® (Magalhães et al., 2016).

The 1,000 results, from scientific knowledge, plotted in practical data visualization form (Figures 2 and 3), provide quick identification for decision making. 81 sub-theme clusters are highlighted. The first 6 are: "treatment during the coronavirus disease (118)" (18.8\%), "risk of coronavirus disease (160)" (16.0\%), "group for coronavirus (153)" (15.3\%), "patients reported (144)" (14.4\%), "develop severe disease (137)" (13.7\%), "causes severe (136)" (13.6\%).

Regarding technological knowledge, it can be measured by the indicator of patents filed in some industrial and/or intellectual property office in a country. Patents are a strong indicator of innovation in science and technology (Antunes \& Mercado, 2000; Freitas \& Segatto, 2014; 
Jorge MAGALHÃES, Henrique KOCH CHAVES, Viviane Theodora MUNIZ. An overview of big data in Covid-19 as a contribution to the management of scientific and technological knowledge

OF MANAGEMENT IN THE $21^{\text {st }}$ CENTURY Vol. 16, No. 2, 2021

108 Leitão, 1981). Even in the extremely recent pandemic environment of COVID-19, one can observe the synergy of scientists and companies in the world, uniting collaborative intelligence and open science, an exponential amount of scientific work has been produced, as seen above, as well as in patents. According to the Intellectual Property Law (No. 9,279/96), a patent application is kept confidential for 18 (eighteen) months from the date of its filing. Therefore, considering that COVID-19 was discovered at the end of 2019, few results of patent filings were to be expected. However, the sharing of scientific and technological data, provided a speed and development of techniques, processes, diagnostic kits and vaccines, in such a way, never seen in the history of mankind.

Regarding patents (technological knowledge), it is noted that $68.5 \%$ refer to the years 2020 and 2021. This fact is justified, since the declaration of pandemic by the WHO occurred almost 02 (two) years ago. Figures 3 and 4 show this evolution and the strong presence of companies, universities and research groups around the world in search of technological innovations and, consequently, a response to the pandemic of the present century. The first 4 (four) applicants with the highest number of patents are Pfizer, Gilead Sciences inc., Center Nat Rech, Crucell Holland. The 10 (ten) countries with the highest number of patents are China (1403), USA (1357), Republic of Korea (240), Netherlands (129), United Kingdom (128), Germany (123), Russian Federation (123), France (100), Japan (94), Canada (84).

\section{Conclusions}

The 21 st century has brought new challenges and great opportunities due to the increasing volume of new data added to the web daily. In the area of Health, it is no different. Scientific and technological knowledge has advanced in an exponential way never seen before. Thus, new ways to identify, extract and treat Big Data in healthcare are essential for decision making.

Open science policies have been increasingly widespread in this new era of the $21 \mathrm{st}$ century, as a response to this scientific and technological advance. In this sense, to help manage scientific and technological knowledge, new solutions have been created to speed up the arduous task of decision-making, especially in Health and in times of pandemic.

As a contribution to managing the knowledge acquired in record time from the COVID-19 pandemic, the scientific backing reached 233,262 thousand publications in the PubMed database alone - originating 81 clusters with 1,000 important documents, 6036 patents related to the coronavirus.

The results indicate that joint efforts of universities and companies towards a greater objective (in this case the coronavirus pandemic), provides effective networking, leading to synergy of results in a short period of time. In this way, tools for identification, extraction, and processing of data (paid or free), favor the quick identification of information for decisionmaking. The scientific and technological big data in coronaviruses, after being shared in essential information, configures a collaborative intelligence made available as an aid in knowledge management.

\section{Acknowledgements}

The authors thank the Pharmaceutical Technology Institute, Farmanguinhos/Fiocruz for the space and infrastructure in carrying out the work. The pharmaceutical company Merck for the release of the student to study for a master's degree at Farmanguinhos/Fiocruz.

\section{Declaration of Interest}

Authors declare no competing interest. 
Jorge MAGALHÃES, Henrique KOCH CHAVES, Viviane Theodora MUNIZ. An overview of big data in Covid-19 as a contribution to the management of scientific and technological knowledge

\section{References}

Agbehadji, I. E., Awuzie, B. O., Ngowi, A. B., \& Millham, R. C. (2020). Review of Big Data analytics, artificial intelligence and nature-inspired computing models towards accurate detection of COVID-19 pandemic cases and contact tracing. International Journal of Environmental Research and Public Health, 17(15), 5330. https://doi.org/10.3390/ijerph17155330

Aleixo, J. A., \& Duarte, P. (2015). Big Data opportunities in healthcare. How can medical affairs contribute? Revista Portuguesa de Farmacoterapia, 7, 230-236.

Antunes, A., \& Mercado, A. (2000). A aprendizagem tecnológica no Brasil: A experiência da indústria química e petroquimica [Technological learning in Brazil: The experience of the chemical and petrochemical industry]. Editora E-papers.

Bonilla-Aldana, D. K., Holguin-Rivera, Y., Cortes-Bonilla, I., Cardona-Trujillo, M. C., García-Barco, A., Bedoya-Arias, H. A., Rabaan, A. A., Sah, R., \& Rodriguez-Morales, A. J. (2020). Coronavirus infections reported by ProMED, February 2000-January 2020. Travel Medicine and Infectious Disease. https://doi.org/10.1016/j.tmaid.2020.101575

Buse, K., \& Waxman, A. (2001). Public-private health partnerships: A strategy for WHO. Bulletin of the World Health Organization, 79(8), 748-754. https://doi.org/10.1590/S0042-96862001000800011

Coronavirus disease 2019. (n.d.). https://www.who.int/emergencies/diseases/novel-coronavirus-2019?gc lid=Cj0KCQjw2PP1BRCiARIsAEqv-pTucWCIRp6LtBdqIo321_Dzgbm-9Kky2CPJqXWBNcw yzKp29ueLpc0aAgarEALw_wcB

Esakandari, H., Nabi-Afjadi, M., Fakkari-Afjadi, J., Farahmandian, N., Miresmaeili, S.-M., \& Bahreini, E. (2020). A comprehensive review of COVID-19 characteristics. Biological Procedures Online, 22(1), 19. https://doi.org/10.1186/s12575-020-00128-2

Fortes, P. A. de C., \& Ribeiro, H. (2014). Saúde Global em tempos de globalização [Global Health in globalization times]. Saúde e Sociedade, 23(2), 366-375. https://doi.org/10.1590/S0104-12902014000200002

Freitas, C. C. G., \& Segatto, A. P. (2014). Science, technology and society from the perspective of social technology: A study from the Critical Theory of Technology. Cadernos EBAPE.BR, 12(2), 302320. https://doi.org/10.1590/1679-39517420

Gray, J., Chambers, L., \& Bounegru, L. (2012). The Data Journalism Handbook, O'Reilly Media, 2012 InfoVis: Wiki. (n.d.). http://www.infovis-wiki.net/index.php?title=Gray,_J._and_Chambers,_L._ and_Bounegru,_L.,_The_Data_Journalism_Handbook,_O\%27Reilly_Media,2012

Haines, A., McMichael, A. J., Smith, K. R., Roberts, I., Woodcock, J., Markandya, A., Armstrong, B. G., Campbell-Lendrum, D., Dangour, A. D., Davies, M., Bruce, N., Tonne, C., Barrett, M., \& Wilkinson, P. (2009). Public health benefits of strategies to reduce greenhouse-gas emissions: Overview and implications for policy makers. The Lancet, 374(9707), 2104 2114. https://doi.org/10.1016/S0140-6736(09)61759-1

Hartz, Z. M.A. (2012). Meta-evaluation of health management: Challenges for "new public health." Ciencia e Saude Coletiva, 17(4), 832-834. Scopus. https://doi.org/10.1590/S1413-81232012000400004

Kira TARAPANOFF (org.). (2015). Analise da Informacao para Tomada de Decisao Desafios e Solucoes [Analysis of information for decision making challenges and solutions] (Vol. 1). Editora Intersaberes. http://www.estantevirtual.com.br/b/kira-tarapanoff/analise-da-informacao-paratomada-de-decisao-desafios-e-solucoes/158550962

Koplan, J. P., Bond, T. C., Merson, M. H., Reddy, K. S., Rodriguez, M. H., Sewankambo, N. K., Wasserheit, J. N., \& Consortium of Universities for Global Health Executive Board. (2009). Towards a common definition of global health. Lancet (London, England), 373(9679), 19931995. https://doi.org/10.1016/S0140-6736(09)60332-9

Laney, D. (2001). 3D Data Management: Controlling Data Volume, Velocity, and Variety (p. 4) [Application Delivery Strategies]. http://blogs.gartner.com/doug-laney/files/2012/01/ad949-3DData-Management-Controlling-Data-Volume-Velocity-and-Variety.pdf

Leitão, D. M. (1981). O conhecimento tecnológico e sua importância. Possibilidades de sua transferência internacional [Technological knowledge and its importance. Possibilities of your international transfer]. Ciência da Informação, 10(2), Article 2. http://revista.ibict.br/ciinf/article/view/149 
Jorge MAGALHÃES, Henrique KOCH CHAVES, Viviane Theodora MUNIZ. An overview of big data in Covid-19 as a contribution to the management of scientific and technological knowledge

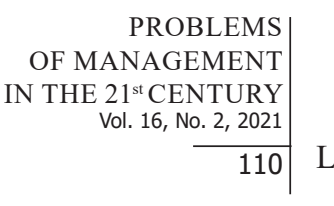

Lima de Magalhães, J., Alves de Oliveira, D., Santos da Costa, J. C., Hartz, Z., Lima de Magalhães, J., Alves de Oliveira, D., Santos da Costa, J. C., \& Hartz, Z. (2020). Strategic vision on the chain of decision in modern competitive scenarios: A case study in material planning in a public company (strategic-vision-on-the-chain-of-decision-in-modern-competitive-scenarios) [Chapter]. IGI Global. https://www.igi-global.com/gateway/chapter/219520

Magalhães, J., Bastos, A. C., \& Barroso, W. (2016). Cenário Global e Glocal das Tendências Científicas e Tecnológicas em Diabetes: Uma Abordagem do Big Data em Saúde no Século 21 [Global and glocal scenario of scientific and technological trends in diabetes: A Big Data approach to health in the 21st century]. Revista Gestão Em Sistemas de Saúde, 5(1), 1-14. https://doi.org/10.5585/rgss.v5i1.191

Magalhães, J., Hartz, Z., Antunes, A., \& Martins, M. do R. O. (2017). An overview of the open science in times of Big Data and innovation to global health. International Journal of Innovation, 5(3), $270-288$.

Magalhães, J. L., \& Quoniam, L. (2013). Perception of the information value for public health: A case study for neglected diseases: library and information science book chapter | IGI Global. In Rethinkin the conceptual base for new practical applications in information value and quality (p. 345). IGI Global. http://www.igi-global.com/chapter/perception-information-value-publichealth/84218

Magalhaes, J. L., \& Quoniam, L. (2015). Percepção do valor da informação por meio da inteligência competitiva 2.0 e do Big Data na saúde [Perception of the value of information through competitive intelligence 2.0 and Big Data in healthcare]. In Análise da Informação para Tomada de Decisão: Desafios e soluções (Vol. 1, p. 365). Kira Tarapanoff (Org.).

McKinsey Global Institute. (2011). Big data: The next frontier for innovation, competition, and productivity | McKinsey Global Institute | Technology \& Innovation | McKinsey \& Company. http://www.mckinsey.com/insights/mgi/research/technology_and_innovation/big_data_the_ next_frontier_for_innovation

Minelli, M., Chambers, M., \& Dhiraj, A. (2013). Big Data, Big Analytics. John Wiey \& Sons. https://books. google.com.br/books/about/Big_Data_Big_Analytics.html?hl=pt-BR\&id=Mg3WvT8uHV4C

O'Reilly, T. (2007a). What is Web 2.0: Design patterns and business models for the next generation of software [SSRN Scholarly Paper]. Social Science Research Network. http://papers.ssrn.com/ abstract $=1008839$

Projeto Genoma Humano: Um retrato da construção do conhecimento cientifico sob a ótica da revista Ciência Hoje [Human Genome Project: A portrait of the construction of scientific knowledge from the perspective of Ciência Hoje magazine]. (n.d.). http://www.scielo.br/scielo.php?script=sci_artt ext\&pid=S1516-73132014000300561

Quoniam, L., \& Lucien, A. (2010). Intelligence compétitive 2.0: Organisation, innovation et territoire. Librairie Lavoisier. http://www.lavoisier.fr/livre/notice.asp?ouvrage $=2139418 \&$ pos $=8$

Resolução do Conselho de Ministros n. ${ }^{\circ}$ 20/2016 - Diário da República n. ${ }^{\circ}$ 70/2016, Série I de 201604-11, 70/2016, Série I de 2016-04-11 (2016). http://legislacaoportuguesa.com/resolucao-doconselho-de-ministros-n-o-202016-diario-da-republica-n-o-702016-serie-i-de-2016-04-11/

Saxena, S. K. (2020). Coronavirus Disease 2019 (COVID-19): Epidemiology, Pathogenesis, Diagnosis, and Therapeutics. Springer Nature.

Strabelli, T. M. V., \& Uip, D. E. (2020). COVID-19 e o Coração. Arquivos Brasileiros de Cardiologia, 114, 598-600. https://doi.org/10.36660/abc.20200209

The Digital Universe in 2020: Big Data, Bigger Digital Shadows, and Biggest Growth in the Far East by John Gantz and David Reinsel sponsored by EMC. (2012). https://www.emc.com/leadership/ digital-universe/2012iview/index.htm

Vance, K., Howe, W., \& Dellavalle, R. P. (2009). Social internet sites as a source of public health information. Dermatologic Clinics, 27(2), 133-136. https://doi.org/10.1016/j.det.2008.11.010

Wong, Z. S. Y., Zhou, J., \& Zhang, Q. (2019). Artificial intelligence for infectious disease Big Data Analytics. Infection, Disease \& Health, 24(1), 44-48. https://doi.org/10.1016/j.idh.2018.10.002

Zhou, C., Su, F., Pei, T., Zhang, A., Du, Y., Luo, B., Cao, Z., Wang, J., Yuan, W., Zhu, Y., Song, C., Chen, J., Xu, J., Li, F., Ma, T., Jiang, L., Yan, F., Yi, J., Hu, Y., ... Xiao, H. (2020). COVID-19: Challenges to GIS with Big Data. Geography and Sustainability, 1(1), 77-87. https://doi.org/10.1016/j.geosus.2020.03.005 
Jorge MAGALHÃES, Henrique KOCH CHAVES, Viviane Theodora MUNIZ. An overview of big data in Covid-19 as a contribution to the management of scientific and technological knowledge

PROBLEMS

OF MANAGEMENT

IN THE $21^{\text {st }}$ CENTURY

Vol. 16, No. 2, 2021

Received: November 15, 2021

Accepted: December 12, 2021

Cite as: Magalhães, J., Koch Chaves, H., \& Muniz, V. T. (2021). An overview of Big Data in Covid-19 as a contribution to the management of scientific and technological knowledge. Problems of Management in the $21^{\text {st }}$ Century, 16(2), 102-111. https://doi.org/10.33225/pmc/21.16.102

\begin{tabular}{|c|c|}
\hline $\begin{array}{l}\text { Jorge Magalhães } \\
\text { (Corresponding author) }\end{array}$ & $\begin{array}{l}\text { PhD, Researcher in Public Health, Oswaldo Cruz Foundation/FIOCRUZ, Far- } \\
\text { manguinhos, Rua Sizenando Nabuco, } 100 \text { - Manguinhos, CEP 21.041-250, } \\
\text { Brazil. } \\
\text { Global Health and Tropical Medicine, GHTM, Institute of Hygiene and Tropical } \\
\text { Medicine, IHMT, NOVA University Lisbon - UNL, Portugal. } \\
\text { E-mail: jorge.magalhaes@fiocruz.br } \\
\text { ORCID: https://orcid.org/0000-0003-2219-5446 }\end{array}$ \\
\hline Henrique Koch Chaves & $\begin{array}{l}\text { PhD, Postdoctoral Student, Oswaldo Cruz Foundation/FIOCRUZ, Farman- } \\
\text { guinhos, Rua Sizenando Nabuco, } 100 \text { - Manguinhos, CEP 21.041-250, Brazil. } \\
\text { E-mail: henrique.chaves@far.fiocruz.br } \\
\text { ORCID: https://orcid.org/0000-0003-3035-6799 }\end{array}$ \\
\hline Viviane Theodora Muniz & $\begin{array}{l}\text { MSc, Regulatory Affairs Specialist, Merck S.A., Brazil. } \\
\text { E-mail: vivianetmuniz@gmail.com } \\
\text { Website: https://www.merckgroup.com/br-pt } \\
\text { ORCID: https://orcid.org/0000-0002-5459-3126 }\end{array}$ \\
\hline
\end{tabular}

